\title{
Childhood Meningioma
}

National Cancer Institute

\section{Source}

National Cancer Institute. Childhood Meningioma. NCI Thesaurus. Code C8264.

A meningioma that occurs during childhood. 